\title{
BUILDING A HOLISTIC CONCEPTUAL FRAMEWORK OF CORPORATE SOCIAL REPORTING FROM AN ISLAMIC PERSPECTIVE
}

\author{
Carol Ann Tilt and Nurliana Md Rahin*
}

\begin{abstract}
The corporate social reporting field, which has been mainly developed in the West, presents theories that neglect the perspective of religion, while the models of corporate social reporting in the current Islamic literature discuss Islamic ethical principles, obligations and social relation system in isolation and are unclear. This article provides a holistic conceptual model of Islamic corporate social reporting by adopting and modifying the models in the literature. Furthermore, it integrates the holistic conceptual model with an explanation of the theories that are common in the West, i.e. Stakeholder Theory and Social Contract Theory, in order to bridge the gap between Western and Islamic perspectives on corporate social reporting.
\end{abstract}

Keywords: Corporate Social Reporting; Ethics; Islam Perspective JEL classification: M14, M41

\section{Introduction}

Corporate social responsibility (CSR) has been debated among social theorists and the business community for many decades. The concept of CSR acknowledges that corporate managers are the trustees of the interests of shareholders and society (Frederick, 1994). The fundamental idea embedded in CSR is that businesses and corporations have an obligation to work for social betterment (Davis and Blomstrom, 1975; Frederick, 1994). As a response to CSR, corporations have to design and establish structures, policies, programmes and processes to ensure that CSR can be applied (Wood, 1991). Stakeholders are also demanding that corporations report their social and environmental performance, making corporations increasingly use corporate social reporting (CSRep) as a mechanism to discharge their duty of accountability (Gray, Owen, and Maunders, 1987). Many theories have been developed in the CSRep literature that try to explain CSRep and to answer why corporations disclose social information. One of the arguments for CSRep is that a corporation is assumed to bear indirect commitments towards society (Garriga and Melé, 2004), which include the duty to discharge accountability. Another powerful theory posits that if the corporation does not appear to operate within the

\footnotetext{
*Corresponding author: Nurliana Md Rahin is Senior Lecturer at the Faculty of Business and Accountancy, University of Malaya, 50603 Kuala Lumpur, Malaysia. Email: lianarahin@um.edu.my. Carol Ann Tilt is a Professor of Accounting at Flinders Business School, Flinders University South Australia, Adelaide 5001, South Australia. Email: carol.tilt@flinders.edu.au
} 
bounds of what is considered appropriate by society, then society may act to remove the corporation's rights to continue operations (Haron, Yahya, Chambers, Manasseh, and Ismail, 2004). Therefore, corporations disclose information as a means of establishing or protecting the legitimacy of the corporation by influencing public opinion (Hackston and Milne, 1996).

These CSRep theories recognize the ethical obligations of businesses and contain the substance of business ethics. The theories envisage business ethics by explaining normative justification for business decisions and ways to reach such decisions (Donaldson and Dunfee, 1994). The CSRep theories articulate ethical expectations and reflect the pattern of business culture, based on moral rationality. According to Donaldson and Dunfee (1994), moral rationality in economic ethics is bounded "by a finite human capacity to access facts, by a limited capacity of ethical theory to capture moral truth, and by a plastic or artifactual nature economic systems and practices" (p.258).

Regardless of the theories utilised, organisations that are considered to be ethical in their business practice are expected to disclose CSR information in their annual reports or separate reports or websites. For some organisations, we have particular reason to expect ethical behaviour; for example, organisations that have religion as the ideological base. However, in corporate social reporting (CSRep) theorization, being solely based on human moral rationality, religion has often been neglected. One problem with current CSRep theories is the lack of inclusion of spiritual thought and values, which may make them insufficient when it comes to explaining CSRep, especially for the Islamic banking system and other Islamic business organizations that incorporate Islamic religious values in their operations.

Frederick (1994) argued that religious values and attitudes are one of the important reasons that give rise to the obligation of corporate social responsibility. Raimi, Patel, Yekini, and Aljadani (2013) contended that Islam and other religions have a relationship with CSR and reporting. Buddhist values, if used as an economic strategy, could also address the paucity of CSR in alleviating the miseries related to the modern economic system (Kovács and Dhammasami, 2011).

However, the existing CSRep theories, which are dominated by Western views, cannot address certain Islamic issues that have been endemic to the West because of the different philosophy and notions. Muslims desire to apply Islamic principles to all aspects of their lives, including their business lives (Vinnicombe, 2010), and these Islamic principles are absent in the CSRep theories.

This paper therefore proposes a normative Islamic perspective as a basis for future CSRep theory specifically for understanding CSRep by Islamic organisations. The paper develops a framework that builds on the context of Islamic countries and the Islamic organizational environment. The proposed conceptual framework for CSRep from an Islamic perspective also integrates existing CSRep theories, particularly the social contract theory and stakeholder theory, but with an approach that places Islamic religious values at the core of 
the framework. This conceptual framework endeavours to provide a holistic approach for the benefit and understanding of Islamic business organizations. Therefore, this paper is not totally divergent from Western-dominated views of CSRep, but provides a supplementary approach for Islamic business organizations, and also elaborates on the normative cultural (religious)-based perspective to help narrow the gaps arising from misunderstanding and misperception. Hence, it helps bridge the gap between the Western and Islamic perspectives.

The framework developed, builds upon existing frameworks, models and literature, to provide a holistic model that can be used in future research. The paper is structured as follows. The next section reviews the literature concerning Islamic organisations and accounting, including outlining existing frameworks that provide the foundations on which the model in this paper is built. Section three describes the holistic conceptual model, and section four concludes the paper.

\section{Literature Review}

Numerous studies have examined the relationships among religion, culture and accounting practices (Baydoun and Willett, 2000; Gray et al., 1987; Gray, 1988). The previous studies show that culture affects accounting and reporting practices around the world, and that religion, which is a subset of culture, has an impact on accounting and reporting (Gray, 1988; Hofstede, 1984). Raimi et al. (2013) contended that Islam and other religions are linked and contribute to CSR and reporting. Islam, Christianity and Judaism could strengthen CSR compliance and reporting through four drivers, i.e. the emotional attachment of the religious believers to their religions; the promotion by the sacred texts (the Holy books) of voluntary charities and philanthropic activities; the celestial rewards and punishments attached to charity, philanthropy and other social activities; and social responsibility is prescribed by these religions as a duty to God (Raimi et al., 2013). Teck Hui (2008) also agreed that the faith values (honouring God, honouring neighbours, honouring creations, honouring commissions, and everlasting principle) of Christians have led their followers to make critical CSR decisions. Furthermore, it is believed that other religions like Buddhism, which teaches the framework of minimizing (to minimize desires, suffering, violence, self-interest and instrumental use), could help realize a genuine CSR (Kovács and Dhammasami, 2011).

However, this paper focuses on the Islamic perspective of CSR and CSRep. Baydoun (1997) found that Islamic belief influences the presentation of information. In the case of the conceptual framework debate concerning the nature of accounting measurement and disclosure from an Islamic perspective, prior literature mainly discusses this from the point of view of Islamic ethical values (Mohammed, 2007; Naqvi, 1981), obligations (Haniffa and Hudaib, 2004; Muwazir and Muhamad, 2006) and social relations system (Maali, Casson, and Napier, 2006; Mohammed, 2007); however, their discussions are 
not holistic enough to explain the entire concept of Islamic corporate social reporting. Each of these aspects is reviewed below, before turning to the integration of these elements into a holistic model.

\subsection{Islam: A Syumul (Complete) Religion}

The literal meaning of Islam is commitment, submission, obedience and surrender (Muwazir and Muhamad, 2006). Islam is not merely about religious beliefs and rituals but a complete way of life that includes involvement in economic activities. In fact, commercial activities are highly regarded in Islam, and Muslims, besides fulfilling their religious duties, are encouraged to work hard and participate in economic activities. Islam is a way of life, i.e. a social order with a complete code of life (Al-Buraey, 1990). Shariah (Islamic moral law) is a code of behaviour for Muslims. The principle of Shariah is based on four main sources:

(i) the Holy Quran (revelation from Allah),

(ii) the Hadith / Sunnah (the deeds, sayings or tacit approval of the Prophet Muhammad),

(iii) the Ijma' (consensus of opinion by the majority of Muslim scholars), and

(iv) the Qiyas (analogy reasoning deducted from the earlier three sources for contemporary issues that are not directly referred to in those sources) (Muwazir and Muhamad, 2006).

Shariah caters for every aspect of a Muslim's life, e.g. spiritual, economic, political and social, and faithful execution of duties and obligations (Hassan and Harahap, 2010).

\subsection{Islamic Ethical Principles}

The first basic principle of Islam is the belief in the existence of Allah (the only God) and the Prophethood of Muhammad, known as Tawhid (Unity). The concept of Tawhid is known as the Unity of God, which is the foundation in the Islamic worldview.

Mohammed (2007) asserts four fundamental ethical principles that bring a unique Islamic perspective. The four fundamental ethical principles are Unity (Tawhid), Equilibrium (Al-Adl), Free Will (Ikhtiyar) and Responsibility (Fardh). Naqvi (1981) has the same opinion that the four fundamental principles can summarise Islamic ethical philosophy. In a similar element to Naqvi's ethical principles, Chapra (1992) asserted that the Islamic worldview is based on three fundamental principles: Unity (Tawhid), Vicegerency (Khilafah) and Justice (Adalah). Vicegerency is a subset of the Unity principle, while Justice is a subset of the Equilibrium principle. Ahmad (1979) argued that an Islamic economic system is rooted in the basic philosophic concepts of Unity (Tawhid), Vicegerency (Khilafah), God's Arrangement (Rubbubiyyah), and 
Growth and Purification (Tazkiyah). Rubbubiyyah refers to God's arrangement for directing things towards a perfect state of human sustenance (Ahmad, 1979).

Muslims believe that there are sufficient resources to sustain everybody to achieve God's perfect plan for the universe (Ahmad, 1979). It is in the context of this divine arrangement that human efforts and responsibility are needed to balance. Because goods are adequately provided by God for every being, greed and self-interest should not exist, since all goods belong to God. As such the concept of God's Arrangement (Rubbubiyyah) is a combination of the principles of Unity, Equilibrium, Free Will and Responsibility. The meaning of Tazkiyah is growth and purification; Muslims believe that the mission of all the Prophets was to perform the Tazkiyah of man in his relationship with God, with other men, and with society (Ahmad, 1979). This requires an individual to expend their best efforts in order to achieve a better material life. However, material wellbeing must lead to social justice and the spiritual enhancement of society (Sulaiman and Willett, 2003). As such the principle of Growth and Purification (Tazkiyah) is related to the principles of Unity and Equilibrium.

This paper focuses on the four principles, as recommended by Mohammed (2007), as the core of the framework, and which are shown in Figure 1. The details of each principle are highlighted in section three.

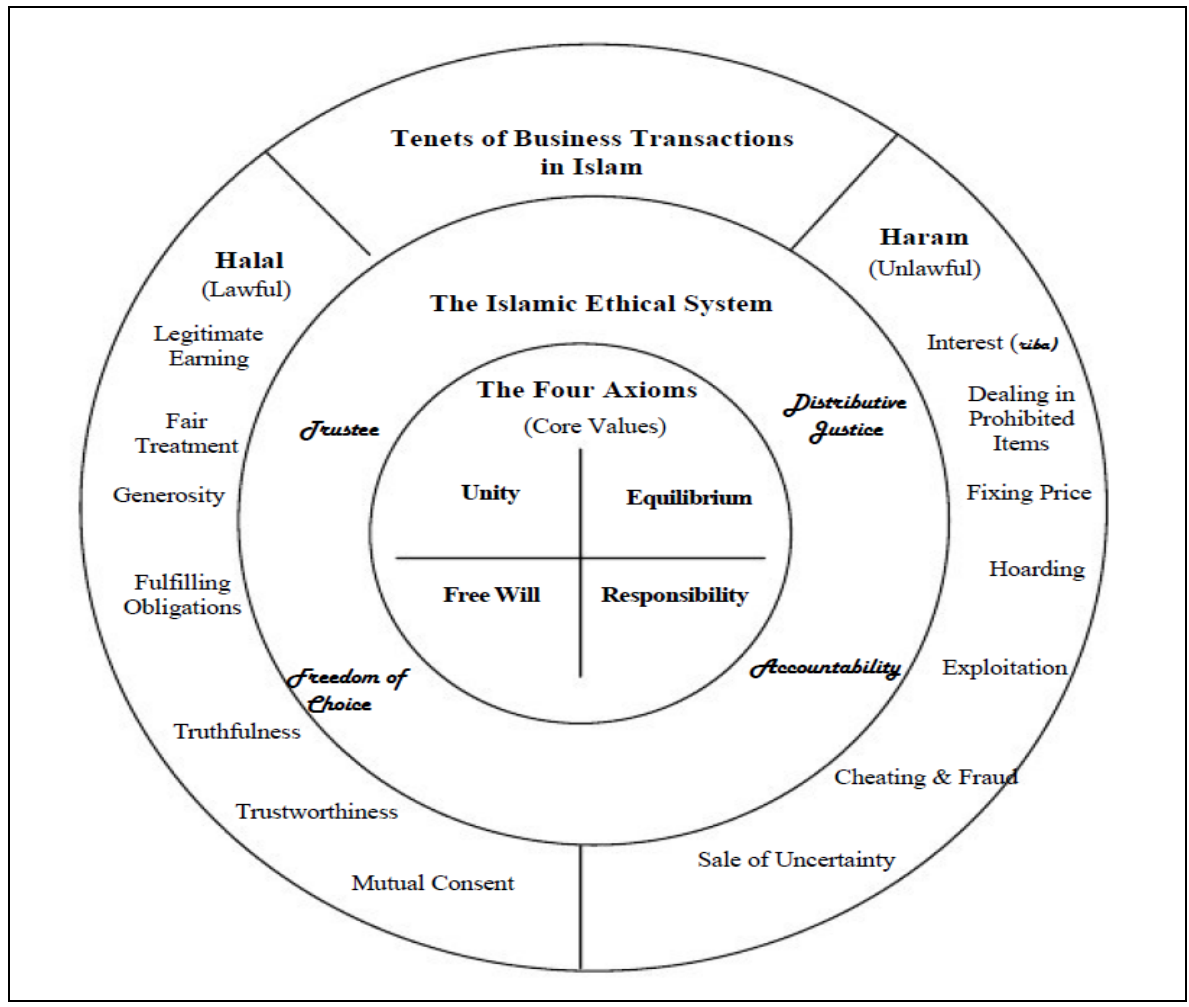

Figure 1: Source: Mohammed (2007) 


\subsection{Relationships and Obligations in Islam}

The relationships or obligations in Islam around the life of Muslims must be dealt with according to the Islamic ethical principles. According to Muwazir and Muhamad (2006), Tawhid encompasses three relationships or obligations in Islam, i.e. man and Allah, man and human beings, and man and the environment, as shown in Figure 2. Man in this context refers to a person of either sex. These relationships should initiate and shape a broader view of corporate social reporting among Islamic business organizations. As Tawhid (unity of God) is the foundation principle, the other Islamic principles that flow after Tawhid are also essential for managing the three relationships in Islam (Muwazir and Muhamad, 2006). Muwazir and Muhamad (2006) developed a model of Islamic corporate social disclosure based on the Tawhid principle. However, their model does not highlight how the other Islamic ethical principles can contribute and strengthen the corporate social disclosure of an Islamic business organization. Thus, this study attempts to address the ethical foundational issues in Islam, along with the work of some other scholars to further develop the conceptual framework for CSRep in Islam.

According to Harahap (2003), accounting is a part of the Tawhid process. Haniffa and Hudaib (2001) argued that the objectives of Islamic accounting are "to assist in achieving socio-economic justice (Al-falah) and recognize the fulfilment of obligation to God, society (including the environment) and individuals concerned, by parties involved in the economic activities viz. accountants, auditors, managers, owner, government, etc. as a form of worship" (cited in Harahap, 2003, p. 77).

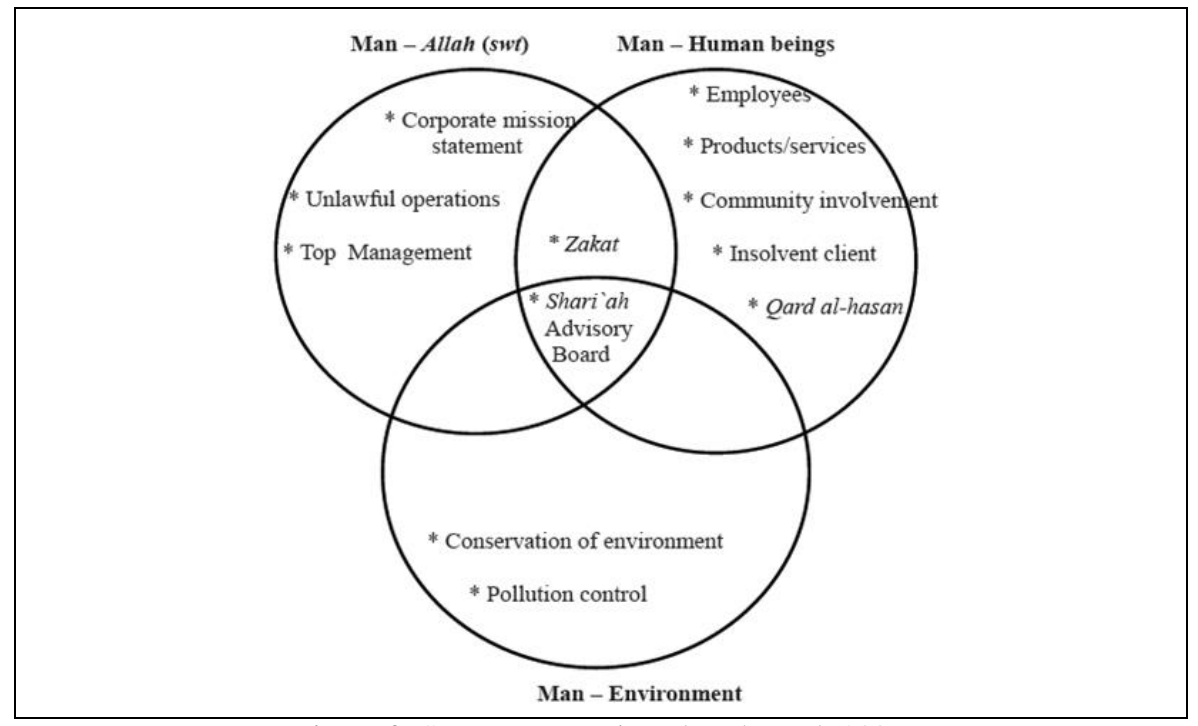

Figure 2: Source: Muwazir and Muhamad (2006) 


\subsection{Islamic Social Relations Systems}

In managing the relationships with Allah, human beings and the environment according to Islamic ethical principles, there needs to be a mechanism or a system to achieve success in those relationships. Maali et al. (2006) considered a social relations system, which is also an appropriate framework to describe the context of social reporting by Islamic business organizations, as represented in Figure 3. Maali et al.'s (2006) framework emphasizes the corporate social reporting in Islam, which is omitted in Mohammed's (2007) study. Some of the elements in Maali et al.'s (2006) social relations framework are similar to the elements of an Islamic ethical system proposed by Mohammed (2007), such as social justice, accountability and trust; however, Mohammed's discussion is directed mainly towards CSR practices rather than reporting. Maali et al.'s (2006) framework discusses social reporting as a medium to demonstrate the social relations promoted by Islam; however, it lacks clarity or content, which directly encompasses the relationships described by Muwazir and Muhamad (2006). Thus, this study endeavours to enhance the social relations system developed by Maali et al. (2006), which stems from the substance of Islamic ethical principles and relationships in Islam.

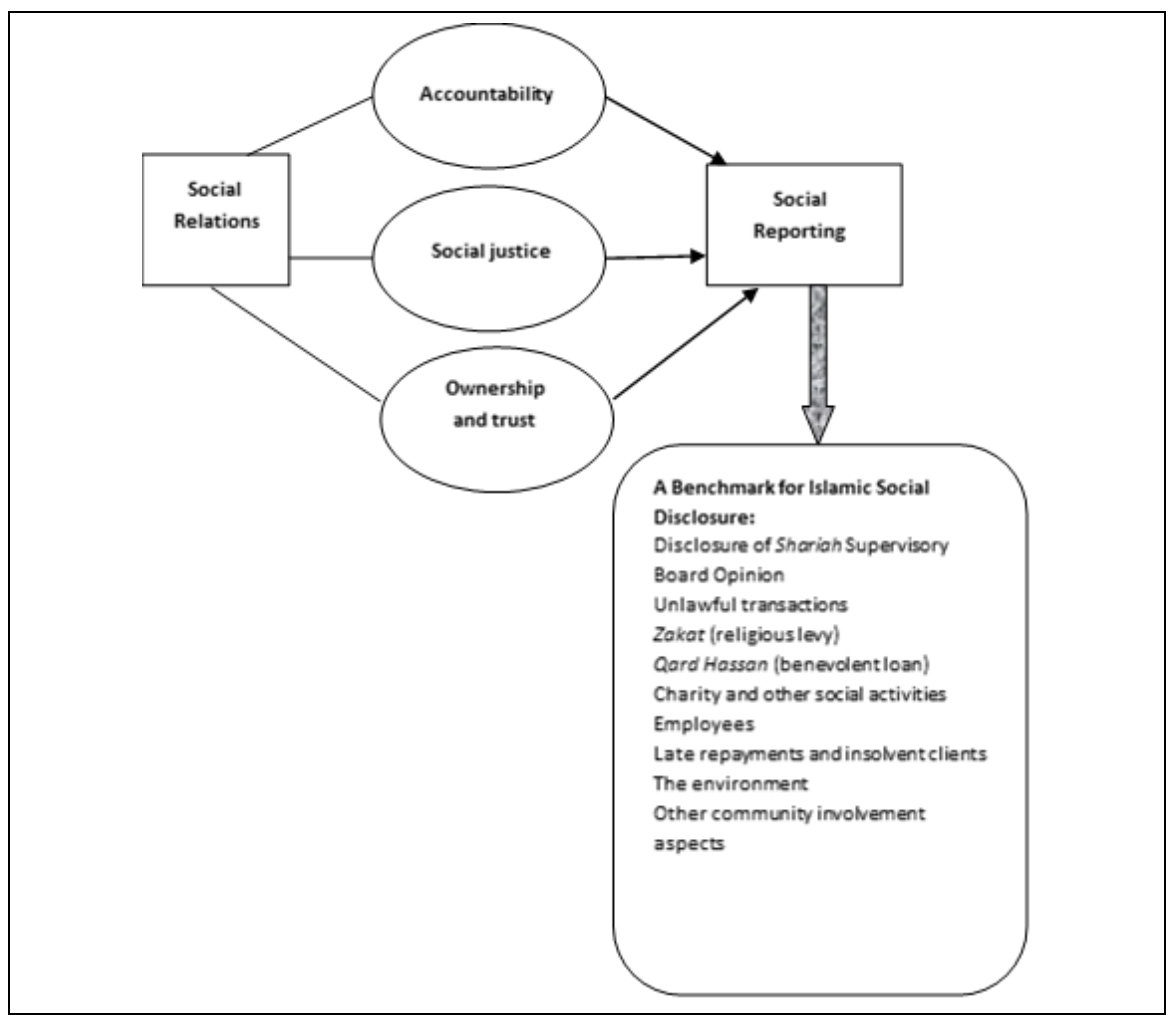

Figure 3: Source: Maali et al. (2006) 


\subsection{Islamic Corporate Social Reporting Models}

The usual model of Islamic CSRep is based on the general criteria for the gathering and communication of accounting information in an Islamic society (N. Baydoun and Willett, 2000). The Islamic CSRep information is important to Muslim stakeholders to help them in making financial decisions and assessing whether or not their actions comply with Shariah (Harahap, 2003). The disclosure of Islamic CSR is consistent with the objectives of Islamic accounting, i.e. "to assist in achieving socio-economic justice (Al-falah) and recognize the fulfilment of obligation to God, society and individuals concerned, by parties involved in the economic activities viz. Accountant, auditors, managers, owner, government, etc. as a form of worship" (Harahap, 2003, p.77).

Maali et al. (2006) proposed a benchmark for Islamic social disclosure, which comprises the disclosure of the Shariah Supervisory Board Opinion, Unlawful transactions, Zakat (religious levy), Qard Hassan (benevolent loan), Charity and other social activities, Employees, and Late repayments and insolvent clients. Muwazir and Muhamad (2006) also proposed similar items for Islamic CSR reporting; however, they added other CSR items that are also considered important in the view of Tawhidic obligations in Islam, i.e. disclosure of Corporate Mission Statement, Top management, Products and services, and the Environment. Although Haniffa and Hudaib (2004) provided several general CSR themes that are suitable for the Islamic banking industry, their list of Islamic CSR items are unspecific as they only include the theme of indication of 'Islamic values'.

In conclusion, the existing CSRep models seem to miss the objective of fulfilling the obligations to God, society and nature in general as certain CSRep models confined the scope of CSRep. For example, the scope of CSRep by Maali et al. (2006) is confined to the themes that directly serve the Islamic ethical principles. Maali et al. (2006) failed to include themes, such as Corporate Mission Statement, Top management, Products and services, and the Environment. Even though these four themes may not be different than the current Western or conventional CSRep, the inclusion of these themes in Islamic CSRep is important because these themes are reported and emphasized differently in a way to serve the Islamic principles. In addition, these four themes (i.e. Corporate Mission Statement, Top management, Products and services, and the Environment) are also important to safeguard the obligations to God, society and nature as a whole. The authors are also acquainted with the conceptual framework of Islamic social reporting proposed by Haniffa (2002), but the framework seems to miss the issues of stakeholders and social pressure, especially among Muslims for social reporting, and fails to show the link between Islamic ethical principles and the obligations to God, society and nature through social reporting. 


\section{Discussion of the Conceptual Framework}

\subsection{A Holistic Islamic CSRep Conceptual Framework}

The proposed conceptual framework for corporate social reporting in Islam presented in this paper is regarded as a holistic model because of the consideration of the whole Islamic worldview in the model. The model is presented in Figure 4 below. As will be seen from the discussion below, the model builds on the foundations provided by previous literature.

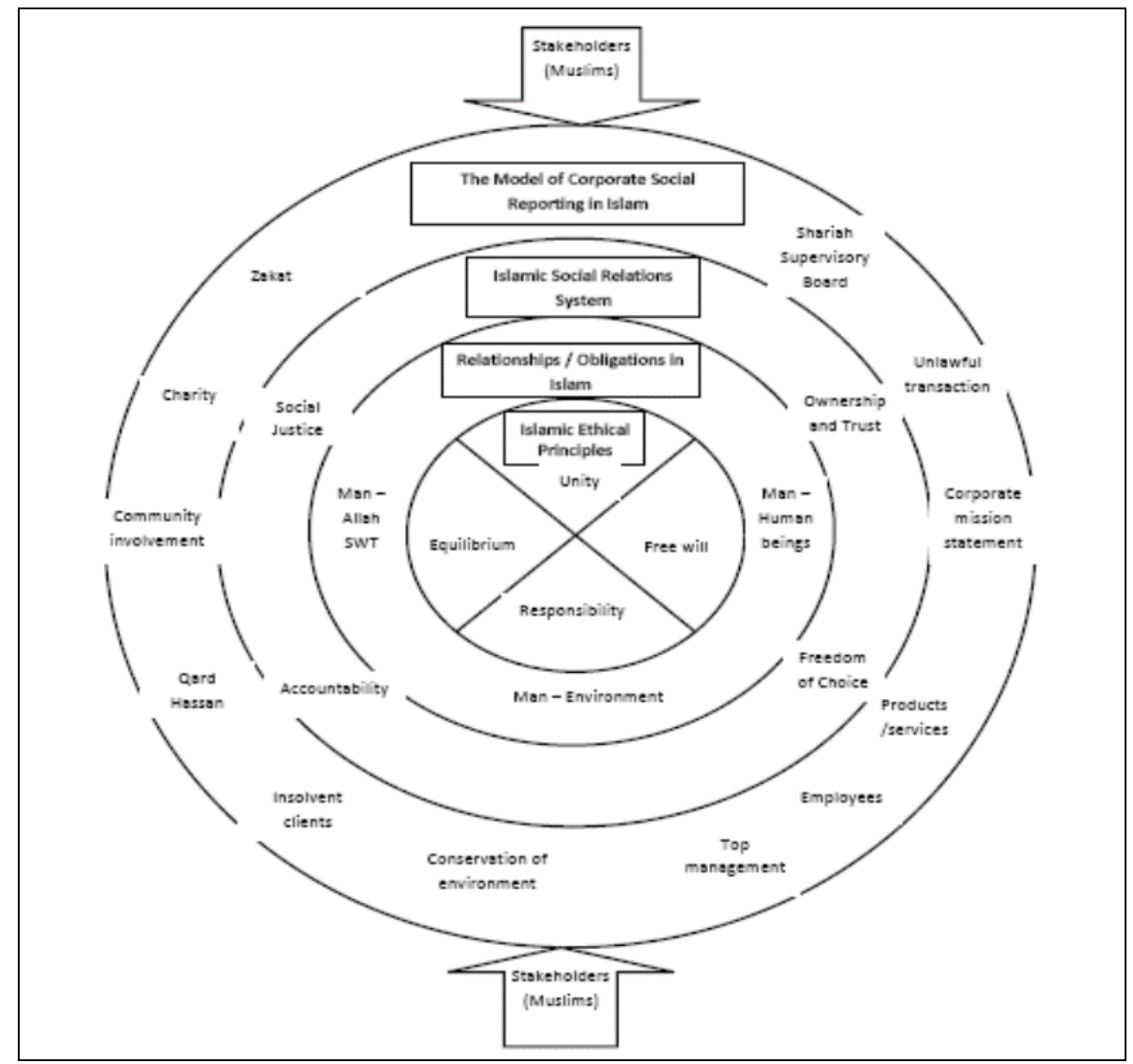

Figure 4: Conceptual Framework of Corporate Social Reporting from an Islamic Perspective (adopted and modified from Maali et al., 2006; Mohammed, 2007; Muwazir and Muhamad, 2006)

The inner circle of the diagram represents the core of the framework, which is the Islamic ethical system; this includes the principles of Unity (Tawhid), Equilibrium (Al-Adl), Free Will (Ikhtiyar) and Responsibility (Fardh). These four principles are adopted from the study by Mohammed (2007), as discussed earlier, which asserts that these principles constitute the systematic framework of corporate social responsibility in Islam. Thus, the Islamic socio-economic 
system is underpinned by these Islamic ethical principles. Mohammed's (2007) four principles of Islam are chosen as the core of the framework because these principles are derived from the works of Naqvi (1981), Chapra (1992), and Ahmad (1979). In addition, Mohammed's (2007) four Islamic principles have been tested empirically in business practice.

Unity (Tawhid) is the foundation of the Islamic worldview, which differentiates the Creator from the created, requiring the unconditional surrender of man to God's Will. The principle of Equilibrium prescribes the relationship amongst individuals. Related to Equilibrium is the concept of justice. From the perspective of the absolute, this refers to the supreme attribute of God. The principle of Free Will is derived from the concept of a "free" man (Naqvi, 1981). Islam recognizes human freedom applying both to the individual man and the collective man and emphasizes a correct balance between the two (Naqvi, 1981). The fourth ethical principle is Responsibility. Responsibility is related to Free Will, but the principle of Responsibility sets limits to what man is free to do by making him responsible for what he does, and, as such, individualism in the Western sense is constrained in Islam (Naqvi, 1981).

The second circle shows the relationships or obligations in Islam around the life of Muslims that must be dealt with according to Islamic ethical principles. These relationships or obligations in Islam are adopted from the study of Muwazir and Muhamad (2006) who proposed an Islamic corporate disclosure model according to Tawhid, which encompasses these three relationships or obligations in Islam. First is the relationship of man with Allah, which involves the sense of love and obedience, complete trust and thoughtfulness, peace and appreciation, steadfastness and active service. Allah is Almighty who knows everything that is hidden or unhidden by human beings. Therefore, it creates the fear of God among Muslims that makes them aware of every action, as actions are closely being watched and recorded in God's book of judgment. Second is the relationship between man and other human beings, which should be based on trust, truthfulness, fairness, respect of law, kindness and tolerance. Every Muslim should always be socially conscious by being generous to their dependents and fulfilling their legitimate needs. In terms of business organizations, management should respect the right of all parties involved, such as shareholders, employees, and suppliers. Third is the relationship between man and the environment because God has created this world and other creations for the life of humans. Therefore, humans are warned not to do mischief in this world. From an Islamic perspective, the deployment and utilization of natural resources for business purposes should ensure that no damage is done to the environment.

The third circle depicts the elements of the Islamic social relations system Accountability, Social Justice and, Ownership and Trust - which are mainly adopted from the study of Maali et al. (2006). First is Accountability in which each individual Muslim has divine accountability to God as well as to the community for all his or her daily activities (Lewis, 2006). As such, accountability is vital to each Muslim's belief (Lewis, 2006). It is the 
responsibility of every Muslim to fulfil the duties and obligations as described in the Holy Quran. Each Muslim is obliged to fulfil the duties and obligations to Allah, to society, and to oneself as well as be accountable to Allah for what man was entrusted with on the Day of Judgment (Haniffa and Hudaib, 2004). Second, is Social Justice, as Islam emphasizes social justice and responsibility in all aspects of human life and society (Kamla and Rammal, 2010). As Muslims are bounded by Akhowa (brotherhood), they have to look after and support each other in society so that no individual will be treated unjustly (Maali et al., 2006). The third element of an Islamic social relations system is Ownership and Trust. The concept of ownership and private property in Islam has a different interpretation compared to that in the West (Sulaiman and Willett, 2003). For Muslims, ownership of wealth is not absolute. Individuals are only trustees; the ultimate ownership of property belongs with God. God has appointed humanity as his vicegerent on earth and has entrusted humanity with stewardship of God's possessions (Lewis, 2001). Lastly, the element of Freedom of Choice, as suggested by Mohammed (2007), is also included in the Islamic social relations system because it evolves from the Islamic ethical principle of Free Will, which signifies that man has freedom to manage the resources in this world even though the ultimate owner is God and man is merely a trustee.

The outer circle describes the disclosure items of corporate social reporting from an Islamic perspective, which are adopted from Maali et al. (2006), and Muwazir and Muhamad (2006). All the disclosure items suggested in the framework are also derived from Islamic ethical principles; as such, Table 1 summarizes how the Islamic ethical principles constitute the disclosure items of corporate social reporting in the framework. The principle of Unity encompasses the basis for relations with God and all that exists regardless of humankind and other creations, which teaches humans to always take action in a courteous and caring manner. According to the principle of Unity, Allah SWT owns all the resources in this world and appoints human beings as His vicegerents (khalifah). As the trustee of Allah's resources on earth, human kind is expected to be trustworthy, not hoard wealth greedily, and be nondiscriminatory. These practices are consistent with the purpose of the creation of mankind, and in line with the spirit of the ownership and trust of the social relations system. Mankind should always realize that Allah entrusts them to manage the resources in this world. This is especially true for Islamic business organizations, which should realize the divine mandate given by God and the trust by the stakeholders to run the business operations. As such, corporate social reporting is appropriate to continuously gain trust from the stakeholders, and, ultimately, the trust from Allah SWT. Therefore, we would expect to see the disclosure of the Shariah Supervisory Board, disclosure of information on products and services, and disclosure about employees being made by Islamic business organizations. The disclosure of the Shariah Supervisory Board and the disclosure of products and services would exhibit the organization's truthfulness in providing products and services that are Shariah-compliant 
together with its assurance. The practice of no wealth hoarding can be seen through the disclosure of products and services, whereby the policies and terms of the products and services should be appropriately disclosed. This includes the disclosure of dealing with clients and customer service, to ensure that the organization does not practice discrimination. Exploitation and discrimination are not acceptable in Islam. Disclosure pertaining to employees, especially related to wages and bonuses, education and training for employees, equal opportunities, working environment and policies relating to religious matters, such as prayer time and place, would help users in assessing whether the organization acts justly and has no discrimination in its dealings with its employees. In general, the disclosure of the Shariah Supervisory Board, disclosure of products and services, and disclosure of employee related information would enable society to assess the extent that the Islamic business organization is practicing the principle of Unity.

Equilibrium is a principle that indicates a balanced sense in all aspects of human life. Humankind, as the vicegerent of Allah in this world, is expected to maintain the equilibrium in society through social responsibility and justice. The Equilibrium principle is mainly related to the relationship between man and other human beings. Man, or an organization, is required to maintain equilibrium in all socio-economic aspects in society, thus ensuring a harmonious society. The equitable distribution of wealth is an important aspect to achieve a balance in society, which, ultimately, would lead to social justice. As such, the Equilibrium principle derives the concept of Social Justice in the social relations system. An Islamic organization, especially an Islamic bank, is expected to apply the practice of profit and loss sharing, as well as benevolent loans, as part of its business operations. Islam encourages the circulation of wealth through trade and prohibits interest or usury (riba). Islamic business organizations are encouraged to expand their capital through trade instead of expanding capital through lending with interest. Lending on interest is harmful to society because the lender, who is likely to be wealthy, lends money to the poorer borrower without the fear of loss, thus creating a greater gap between the rich and the poor in society. It is essential for Islamic banks to distribute their profit by means of benevolent loans to the wider society. Islamic banks, which have extra profits in reserve, can disburse the money as a benevolent loan. Benevolent loans can benefit society as well as foster the equitable distribution of wealth. Thus, the disclosure of social information related to equilibrium and social justice is important to denote that an Islamic business organization is socially just. We would expect Islamic business organizations, such as Islamic banks, to disclose information related to business, and social savings and investments, Qard Hassan (benevolent loan) and Zakat (religious levy). The disclosure of business, and social savings and investments indicates that Islamic banks practice the principle of equilibrium or distributive justice through profit and loss sharing on investments, especially related to socially motivated investments and projects, venture capital (mudarabah), pawn-broking and micro-financing. The disclosure of information on these financing facilities will 
show a strong commitment by Islamic banks towards the social dimension, specifically that they give priority to projects and investments that emphasize social contributions, and stimulate equality and social justice in society. Second is the disclosure of Qard Hassan (benevolent loan) or non-interest bearing loan, which shows the bank's commitment to the social dimension that includes the disadvantaged segments in society. Third is the disclosure of Zakat, which is a useful tool to ensure equality in the distribution of wealth. Zakat is a religious levy through which it is compulsory for the rich to pay a considerable portion of wealth and then redistribute among the poor. Roy (2010) asserted that the "Muslim world had the zakat, a form of religious tax designed to help the poor, long before the U.S. or Europe developed systemic philanthropic responses" (p.53). The disclosure of Zakat is also important for users, so that they can determine whether the Islamic banks pay Zakat on business income as well as on behalf of the shareholders and depositors.

The Free Will principle is the freedom to choose. Freedom of choice in the social relations system is derived from the principle of Free Will. Mankind is given freedom from Allah to choose the way to manage the resources in this world. However, the freedom must be used in accordance with Shariah in order to gain blessing from Allah. The free will principle is also related to the primeval nature of creation. Every man has a state of intrinsic goodness and the conscious expression of this rests with humankind. Therefore, Muslims are expected to contribute to society, fulfil all obligations pertaining to their social responsibility and care for the less fortunate. As such, the Free Will principle closely explains the way to manage the relationship of man with other human beings and also nature. Therefore, Islamic business organizations are expected to disclose information on charity and other social activities, other community involvement aspects, late repayments/insolvent clients, and conservation of the environment. Activities, such as charities (saddaqa) and trusts (waqf), can fulfil the needs of the ummah or public at large. Thus, it is important for Islamic business organizations to disclose their role in enhancing economic development and addressing social problems, for example, housing, literacy, and scholarships of the societies in which they operate (Maali et al., 2006). Islamic business organizations are also prohibited from being involved in any activity that might destroy or harm the environment. As such, information related to the use of resources and programmes undertaken to protect the environment should be disclosed.

The Responsibility principle establishes the tripartite relationship between God, humankind and nature. Allah SWT created everything for humankind and appointed us to be His vicegerent on this world. This role is trusteeship, which imposes a moral responsibility. This assumption of responsibility makes humankind accountable for their actions. Thus, the Responsibility principle derives the concept of Accountability in the social relations system. According to Ishaque (1978), the concept of Accountability in Islam comprises the fundamental principles of full disclosure and social accountability, in which the latter is in fact a subset of the former (as cited by Sobhani, Zainuddin, and 
Amran, 2010). Social accountability means that a Muslim, or Islamic organization, is accountable to demonstrate social responsibility and promote social justice, and thus is expected to discharge their accountability through full disclosure. As such it is difficult for a business organization to be accountable if there is no disclosure or reporting. In adherence to the Responsibility principle, Islamic business organizations are expected to demonstrate accountability, make management decisions based on Shariah and fulfil their responsibility as an organization towards society. As such, we expect Islamic business organizations to disclose any unlawful transactions because accountability means being faithful in every action. Management is accountable to ensure that the organization operates in accordance with Shariah principles from top to bottom in the hierarchy. Management also needs to ascertain that the organization is achieving both goals of commercial success and fulfilment of social responsibility. Therefore, we would expect to see the disclosure of top management and corporate mission statements.

Table 1 summarizes the fundamental Islamic ethical principles that constitute the conceptual framework of corporate social reporting in Islam. In Table 1, some other issues that are considered for each social reporting practice are shown. The arrows pointing inwards in the model in Figure 4, show the social pressure for corporate social disclosure, which is expected to be faced by Islamic business organizations, especially from Muslim stakeholders. Further discussion regarding Muslim stakeholders is emphasized in the next section.

\subsection{The Incorporation of Stakeholder Theory and Social Contract Theory within an Islamic Perspective}

We have established that the objective of Islamic accounting is to help Muslim stakeholders to obtain information that can help them to assess whether a firm's actions comply with Shariah, achieve socio-economic justice and recognize the fulfilment of obligations; therefore, Islamic banks should be responsible to Muslim stakeholders by analysing their information needs and managing their demands. In the relationship between an Islamic business organization and its stakeholders, any conflicting demands of the stakeholders are able to be dealt with and balanced by the Islamic ethical principles because each key ethical issue faced by multiple stakeholders can be prioritized using the Islamic approaches of justice, trust and benevolence (Beekun and Badawi, 2005). The Islamic ethical system seeks to respect the rights of stakeholders regardless of whether they are from primary or secondary stakeholder groups. Islam promotes a multi-fiduciary stakeholder approach that regulates what various stakeholders of a business receive in accordance with their inputs. 
Table 1: Summary of Fundamental Islamic Ethical Principles that Constitute the Conceptual Framework of Corporate Social Reporting in Islam

\begin{tabular}{|c|c|c|c|c|}
\hline *Islamic Ethical Principles & *Proposition & $\begin{array}{l}\text { *Key Features } \\
\text { (Expectation/ Application } \\
\text { in Business Practice) }\end{array}$ & $\begin{array}{l}\text { Expectation in Corporate Social } \\
\text { Reporting Practices }\end{array}$ & Issues Considered \\
\hline \multirow{3}{*}{ Unity } & \multirow{3}{*}{$\begin{array}{l}\text { There is only one God - } \\
\text { Allah (SWT) and everything } \\
\text { in the earth belongs to Him. } \\
\text { Man is considered as } \\
\text { vicegerent of Allah (SWT) } \\
\text { on earth and thus trustee of } \\
\text { Allah's (SWT) resources }\end{array}$} & \multirow{3}{*}{$\begin{array}{l}\text { Trustworthiness } \\
\text { Avoid hoarding wealth } \\
\text { avariciously }\end{array}$} & $\begin{array}{l}\text { Disclosure of Shariah Supervisory } \\
\text { Board }\end{array}$ & $\begin{array}{l}\text { - Report of Shariah } \\
\text { supervisory board opinion } \\
\text { - Details regarding the } \\
\text { members of the Shariah } \\
\text { supervisory board }\end{array}$ \\
\hline & & & Disclosure of Products/services & 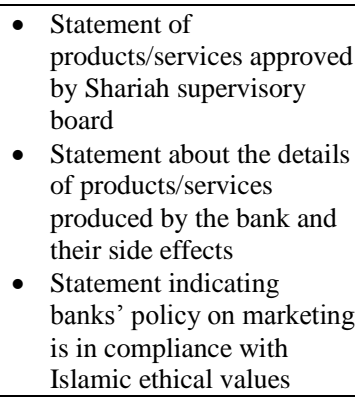 \\
\hline & & & Disclosure of Employees & $\begin{array}{l}\text { Policies for wages and } \\
\text { bonuses payment, } \\
\text { education and training for } \\
\text { employees, equal } \\
\text { opportunities, and the } \\
\text { working environment }\end{array}$ \\
\hline
\end{tabular}


Tilt, C. A. and Md Rahin, N.

\begin{tabular}{|c|c|c|c|c|}
\hline *Islamic Ethical Principles & *Proposition & $\begin{array}{l}\text { *Key Features } \\
\text { (Expectation/ Application } \\
\text { in Business Practice) }\end{array}$ & $\begin{array}{l}\text { Expectation in Corporate Social } \\
\text { Reporting Practices }\end{array}$ & Issues Considered \\
\hline \multirow[t]{2}{*}{ Equilibrium } & \multirow[t]{2}{*}{$\begin{array}{l}\text { Various elements of life must } \\
\text { be equilibrated to produce the } \\
\text { best social order, which is a } \\
\text { conglomeration of natural } \\
\text { and social forces creating } \\
\text { social harmony }\end{array}$} & \multirow[t]{2}{*}{ Profit and loss sharing } & Disclosure of Zakat & $\begin{array}{l}\text { - Statement of sources and } \\
\text { uses of Zakat } \\
\text { Balance of the Zakat fund, } \\
\text { and reasons for non- } \\
\text { distribution } \\
\text { - Shariah supervisory board } \\
\text { affirmation regarding the } \\
\text { computation and } \\
\text { distribution of the zakat } \\
\text { funds }\end{array}$ \\
\hline & & & Disclosure of Qard al-Hassan & $\begin{array}{l}\text { - } \\
\text { - } \quad \text { uses of the Qard funds } \\
\text { Policies for providing } \\
\text { Qard loans and for } \\
\text { dealing with insolvent } \\
\text { beneficiaries }\end{array}$ \\
\hline \multirow{2}{*}{ Free will } & \multirow{2}{*}{$\begin{array}{l}\text { As a trustee of Allah's } \\
\text { (SWT) resources on earth, } \\
\text { mankind has been given the } \\
\text { free will to steer his/her own } \\
\text { life. Unlike other creatures in } \\
\text { Allah's (SWT) universe, } \\
\text { humans can choose to behave } \\
\text { either ethically or unethically }\end{array}$} & \multirow[t]{2}{*}{$\begin{array}{l}\text { Contribution to the well- } \\
\text { being of society }\end{array}$} & $\begin{array}{l}\text { Disclosure of charity and other } \\
\text { social activities }\end{array}$ & 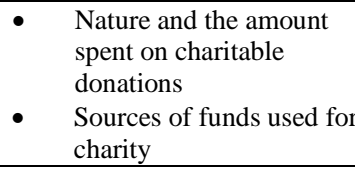 \\
\hline & & & $\begin{array}{l}\text { Disclosure of other community } \\
\text { involvement aspects }\end{array}$ & $\begin{array}{l}\text { The role of banks in } \\
\text { enhancing economic } \\
\text { development and } \\
\text { addressing social } \\
\text { problems }\end{array}$ \\
\hline
\end{tabular}


Building A Holistic Conceptual Framework of Corporate Social Reporting from an Islamic Perspective

\begin{tabular}{|c|c|c|c|c|}
\hline *Islamic Ethical Principles & *Proposition & $\begin{array}{l}\text { *Key Features } \\
\text { (Expectation/ Application } \\
\text { in Business Practice) }\end{array}$ & $\begin{array}{l}\text { Expectation in Corporate Social } \\
\text { Reporting Practices }\end{array}$ & Issues Considered \\
\hline & & \multirow[t]{3}{*}{ society } & $\begin{array}{l}\text { Disclosure of late } \\
\text { repayments/Insolvent clients }\end{array}$ & $\begin{array}{l}\text { Policy in dealing with } \\
\text { late payments by clients } \\
\text { and insolvent clients } \\
\text { Shariah supervisory } \\
\text { board opinion regarding } \\
\text { the permissibility of } \\
\text { penalty charges on late } \\
\text { payments }\end{array}$ \\
\hline & & & \multirow{2}{*}{$\begin{array}{l}\text { Disclosure of conservation of } \\
\text { environment }\end{array}$} & $\begin{array}{l}\text { Nature and amount of } \\
\text { donations or activities for } \\
\text { conserving the } \\
\text { environment }\end{array}$ \\
\hline & & & & $\begin{array}{l}\text { Whether the bank has } \\
\text { financed any projects that } \\
\text { may directly or indirectly } \\
\text { harm the environment }\end{array}$ \\
\hline Responsibility & $\begin{array}{l}\text { Every individual is } \\
\text { accountable and ultimately } \\
\text { responsible for his own } \\
\text { actions }\end{array}$ & $\begin{array}{l}\text { Accountability } \\
\text { Management decisions of } \\
\text { accountability based on } \\
\text { Shariah } \\
\text { Fulfilling the responsibility as }\end{array}$ & $\begin{array}{l}\text { Disclosure of corporate mission } \\
\text { statement }\end{array}$ & $\begin{array}{l}\text { - Statement stating that the } \\
\text { company's operations are } \\
\text { based on Shariah } \\
\text { principles and } \\
\text { emphasizing on the } \\
\text { importance of earning } \\
\text { halal (permissible) profit }\end{array}$ \\
\hline
\end{tabular}


Tilt, C. A. and Md Rahin, N.

\begin{tabular}{|c|c|c|c|c|}
\hline *Islamic Ethical Principles & *Proposition & $\begin{array}{l}\text { *Key Features } \\
\text { (Expectation/ Application } \\
\text { in Business Practice) }\end{array}$ & $\begin{array}{l}\text { Expectation in Corporate Social } \\
\text { Reporting Practices }\end{array}$ & Issues Considered \\
\hline & & \multirow[t]{2}{*}{$\begin{array}{l}\text { an organization towards } \\
\text { society }\end{array}$} & Disclosure of unlawful transactions & $\begin{array}{l}\text { Nature of the unlawful } \\
\text { transactions } \\
\text { Amount of revenue and } \\
\text { expenses from the } \\
\text { unlawful transactions } \\
\text { Reasons for undertaking } \\
\text { unlawful transactions } \\
\text { How the banks disposed, } \\
\text { or intend to dispose of } \\
\text { revenues from unlawful } \\
\text { transactions }\end{array}$ \\
\hline & & & Disclosure of top management & $\begin{array}{l}\text { Details of BOD members } \\
\text { and management team } \\
\text { Policy in appointing, re- } \\
\text { appointment and } \\
\text { dismissal of } \\
\text { BOD/management team }\end{array}$ \\
\hline
\end{tabular}


All Muslims must always remember their role as God's trustees on earth, and, as such, the responsibility of each stakeholder is heavily based on trust, equity, balance and benevolence. For example, the goal of an Islamic business organization is to balance the need to maximize value while respecting the needs of other stakeholders through the prohibition of interest (riba). To avoid interest-based transactions, Islam encourages business partnerships where all parties share equally in the risk of gain and/or loss. As such, Trust (amanah) plays an important role in business, e.g. in partnerships or Mudharabah (a profit and loss sharing arrangement) in Islamic banks. An Islamic business organization is also a trustee and is obligated to disclose all the information regarding interest (riba) and profit and loss sharing on investment, and to be accountable for the discharge of this information (Beekun and Badawi, 2005). For Islamic business organizations, disclosing the Islamic CSR items is part of the Uqud (contracts) in Islam. The concept of Uqud is similar to the Social contract theory; however, Islam stresses a comprehensive understanding of the various contractual relationships in human life and the fulfilment of obligations includes both explicit contracts and tacit contracts. In Islam, the faithful execution of all obligations of contracts, especially tacit contracts, is recognised as ibadah (worship Allah) (Haniffa and Hudaib, 2004). Through this social contract, an Islamic business organization is required to run its operations in socially responsible ways and ways implicitly anticipated by society (Muslim stakeholders), but with enforcement mechanisms as a Muslim and God's trustee to apply all Islamic ethical principles in all aspects of business operations.

\section{Conclusion}

Islam is a complete religion and a way of life. Consequently, Islam prohibits secularism, which separates the world and spiritual matters. As such the current CSRep theories, which are Western-dominated, secularist, based on rational inquiry and argument, relative and ever changing, are not sufficient to explain CSRep in Islamic business organizations. Thus, this study proposes a conceptual framework that incorporates Islamic ethical principles as the spiritual core of the framework. The study also attempts to integrate the Western CSRep theories of stakeholder and social contract theory with a model based on spiritual values.

In Islam, Islamic ethical principles are very important, especially Unity (Tawhid), which means the belief in the Unity of God from which the rest of the Islamic ethical principles are derived. As Islam is a way of life, these Islamic ethical principles must be applied in every aspect of life, including business activities. Islam and business ethics are inseparable and the guidance, i.e. Shariah (Islamic law), is already provided in Islamic teachings, which can be obtained from four main sources (Holy Quran, Hadith, Ijma' and Qiyas).

In this paper, the conceptual framework endeavours to provide a holistic approach for the benefit and understanding of Islamic business organizations. It provides a basis for determining the expected reporting activities of Islamic 
organisations, upon which empirical research can be undertaken. The model presented consolidates various frameworks and models, as previous research has only considered these aspects in isolation, and most ignore the valuesreporting link.

This study focuses on normative CSRep from an Islamic perspective; therefore, future research should consider conducting empirical studies on whether and how Islamic ethical principles can lead corporate managers in Islamic business organizations to apply the expected business practices and the expected corporate social reporting. Furthermore, future research may consider examination of the relationship between the expected corporate social reporting and the financial performance of the Islamic organisations, particularly Islamic banks, which may help to enhance the understanding of the dual social and financial role of Islamic banks in Islamic society.

\section{References}

Ahmad, K. (1979). Economic Development in an Islamic Framework. Leicester: The Islamic Foundation.

Al-Buraey, M. (1990). Management and Administration in Islam. Dharan: King Fahd University of Petroleum and Minerals.

Baydoun, N., \& Willett, R. (1997). Islam and accounting: ethical issues in the presentation of financial information. Accounting, Commerce \& Finance: The Islamic Perspective, 1(1), 1-25.

Baydoun, N., \& Willett, R. (2000). Islamic corporate reports. Abacus, 36(1), 7190.

Beekun, R. I., \& Badawi, J. A. (2005). Balancing ethical responsibility among multiple organizational stakeholders: The Islamic perspective. Journal of Business Ethics, 60(2), 131-145.

Chapra, M. U. (1992). Islam and the economic challenge. Leicester: International Institute of Islamic Thought.

Davis, K., \& Blomstrom, R. L. (1975). Business and society: Environment and responsibility. NY: McGraw-Hill New York.

Donaldson, T., \& Dunfee, T. W. (1994). Toward a unified conception of business ethics: Integrative social contracts theory. Academy of Management Review, 19(2), 252-284.

Frederick, W. C. (1994). From Csr1 to Csr2. Business \& Society, 33(2), 150.

Garriga, E., \& Melé, D. (2004). Corporate social responsibility theories: mapping the territory. Journal of Business Ethics, 53(1), 51-71.

Gray, R., Owen, D., \& Maunders, K. (1987). Corporate social reporting: Accounting and accountability. London: Prentice-Hall.

Gray, S. J. (1988). Towards a theory of cultural influence on the development of accounting systems internationally. Abacus, 24(1), 1-15.

Hackston, D., \& Milne, M. J. (1996). Some determinants of social and environmental disclosures in New Zealand companies. Accounting, Auditing \& Accountability Journal, 9(1), 77-108. 
Haniffa, R. (2002). Social reporting disclosure: an Islamic perspective. Indonesian Management \& Accounting Research, 1(2), 128-146.

Haniffa, R., \& Hudaib, M. (2004). Disclosure Practices of Islamic Financial Institutions: An Exploratory Study. Working paper No. 04/32. Bradford University School of Management.

Haniffa, R., \& Hudaib, M. (2001). A Conceptual for Islamic Accounting: the Shariah Paradigm. Working Paper, International Conference on Accounting, Auditing and Finance. Palmerstone North, New Zealand.

Harahap, S. S. (2003). The disclosure of Islamic values-annual report. The analysis of Bank Muamalat Indonesia's annual report. Managerial Finance, 29(7), 70-89.

Haron, H., Yahya, S., Chambers, A., Manasseh, S., \& Ismail, I. (2004). Level of corporate social disclosure in Malaysia. Paper presented at the Fourth Asia Pasific interdisciplinary Research in Accounting Conference, Singapore.

Hassan, A., \& Harahap, S. S. (2010). Exploring corporate social responsibility disclosure: the case of Islamic banks. International Journal of Islamic and Middle Eastern Finance and Management, 3(3), 203-227.

Hofstede, G. H. (1984). Culture's consequences: International differences in work-related values. London: Sage Publications, Inc.

Ishaque, M. K. (1978). Islamic Law: Its Ideals and Principles. In A. Gauhar (Ed.), The Challenge of Islam. London: Islmaic Council of Europe.

Kamla, R., \& Rammal, H. G. (2010). Social reporting by Islamic banks: Does social justice matter? Paper presented at the 6th Asia Pacific Interdisciplinary Research in Accounting (APIRA) Conference, Sydney, Australia.

Kovács, G., \& Dhammasami, K. (2011). The Buddhist solution for the deficiencies of corporate social responsibility (CSR). Paper presented at the Buddhist virtues for social and economic development: Conference proceeding of the 8th International Buddhist Conference on the United Nations Day of Vesak Celebrations in Bangkok, Thailand.

Lewis, M. K. (2001). Islam and accounting. Accounting Forum, 25(2), 103-127. doi: 10.1111/1467-6303.00058

Lewis, M. K. (2006). Accountability and Islam. Paper presented at the 4th international conference on accounting and finance in transition (ICAFT 2006), Adelaide, South Australia. http://arrow.unisa.edu.au:8081/1959.8/50451

Maali, B., Casson, P., \& Napier, C. (2006). Social reporting by islamic banks. Abacus, 42(2), 266-289. doi: 10.1111/j.1467-6281.2006.00200.x

Mohammed, J. A. (2007). Corporate Social Responsibility in Islam. (Ph.D), Auckland University of Technology Auckland, New Zealand.

Muwazir, M. R., \& Muhamad, R. (2006). Islamic Business Organizations (Ibos) and Corporate Social Disclosure (CSD): A Tawhidic Paradigm. Paper presented at the International Conference on Environmental Challenges of Service Industry in Asia Pasific, Bukit Tinggi, Indonesia. 
Naqvi, S. N. H. (1981). Ethics and economics An Islamic synthesis. UK: The Islamic Foundation.

Raimi, L., Patel, A., Yekini, C. O., \& Aljadani, A. (2013). Exploring the theological foundation of corporate social responsibility in Islam, Christianity and Judaism for strengthening compliance and reporting: An eclectic approach. Issues in Social and Environmental Accounting, 7(4), 228-249.

Roy, D. A. (2010). Trends in global corporate social responsibility practices: The case of Sub-Saharan Africa. International Journal of Civil Society Law., 8(3), 64.

Sobhani, F. A., Zainuddin, Y., \& Amran, A. (2010, 23-24 December 2010). Religion as an Emerging Institutional Factor behind Sustainability Disclosure Practices in Bangladesh: The Case of an Islamic Bank. Paper presented at the 4th Asian Business research Conference, Dhaka, Bangladesh.

Sulaiman, M., \& Willett, R. (2003). Using the Hofstede-Gray Framework to Argue Normatively for an Extension of Islamic Corporate Reports. Malaysian Accounting Review, 20(1), 81-104.

Teck, H. L. (2008). Combining faith and CSR: a paradigm of corporate sustainability. International Journal of Social Economics, 35(6), 449-465.

Vinnicombe, T. (2010). AAOIFI reporting standards: Measuring compliance. Advances in Accounting, 26(1), 55-65.

Wood, D. J. (1991). Corporate Social Performance Revisited. Academy of Management Review, 16, 691-718. 